\title{
PENGARUH CITRA DESTINASI WISATA DAN KUALITAS LAYANAN TERHADAP KEPUASAN PENGUNJUNG DI PANTAI TIGA WARNA
}

\author{
Winda Septiandari ${ }^{1}$, Syarif Hidayatullah ${ }^{2}$, Stella Alvianna ${ }^{3}$, dan Aprilia \\ Rachmadian $^{4}$, Dewi Hermin Sutanto 5 \\ septiandariwinda@gmail.com \\ Universitas Merdeka Malang
}

\begin{abstract}
ABSTRAK
Penelitian ini bertujuan untuk menganalisis hubungan Citra Destinasi Wisata dan Kualitas Layanan terhadap Kepuasan Pengunjung di Pantai Tiga Warna, Kabupaten Malang. Penelitian ini merupakan penelitian kuantitatif dengan variabel bebas yaitu Citra Destinasi Wisata dan Kualitas Layanan serta variabel terikat yaitu Kepuasan Pengunjung. Teknik pengumpulan data menggunakan kuesioner. Pada penelitian ini terdapat populasi sebesar 16.800 yang didapat dari data historis pengunjung Pantai Tiga Warna, Kabupaten Malang pada periode Januari-Agustus 2020. Teknik sampling yang digunakan adalah purposive sampling, dengan 100 responden yang telah melakukan kunjungan ke Pantai Tiga Warna. Analisis data menggunakan analisis regresi linier berganda dan uji hipotesis. Dari hasil penelitian ini dapat disimpulkan bahwa Citra Destinasi Wisata dan Kualitas Layanan baik secara parsial ataupun simultan memiliki pengaruh yang positif dan signifikan terhadap Kepuasan Pengunjung di Pantai Tiga Warna. Berdasarkan penelitian yang dilakukan, maka dapat diberikan beberapa rekomendasi berupa saran-saran yang dapat menjadi bahan pertimbangan bagi pihak pengelola Pantai Tiga Warna yaitu senantiasa meningkatkan citra wisata dengan meyakinkan wisatawan untuk melakukan kegiatan wisata, meningkatkan standar wisata, serta memperhatikan kebersihan lingkungan.

Kata Kunci: Citra Destinasi Wisata, Kualitas Layanan, Kepuasan

Pengunjung, Purposive Sampling, Regresi Linier

Berganda, Uji Hipotesis
\end{abstract}

\section{ABSTRACT}

This study aims to analyze the relationship between Tourist Destination Image and Service Quality on Visitor Satisfaction at Tiga Warna Beach, Malang Regency. This research is a quantitative study with the independent variables namely Tourist Destination Image and Service Quality and the dependent variable is Visitor Satisfaction. Data collection techniques using a questionnaire. In this study, there was a population of 16,800 obtained from historical data of visitors to Tiga Warna Beach, Malang Regency in the January-August 2020 period. The sampling technique used was purposive sampling, with 100 respondents who had visited Tiga Warna Beach. Data analysis used multiple linear regression analysis 
and hypothesis testing. From the results of this study, it can be concluded that the image of tourist destinations and service quality, either partially or simultaneously, has a positive and significant influence on visitor satisfaction at Tiga Warna Beach. Based on the research conducted, several recommendations can be given in the form of suggestions that can be taken into consideration for the managers of Tiga Warna Beach, namely to always improve the image of tourism by convincing tourists to carry out tourism activities, improve tourism standards, and pay attention to environmental cleanliness.

Keywords: Tourist Destination Image, Service Quality, Visitor

Satisfaction, Purposive Sampling, Multiple Linear

Regression, Hypothesis Testing

\section{PENDAHULUAN}

Jawa Timur adalah salah satu provinsi di Indonesia yang memiliki potensi wisata pantai dan bahari yang sangat beragam, baik di sisi utara maupun di sisi selatan. Kabupaten Malang Selatan adalah salah satu tujuan pariwisata yang belakangan ini sedang berkembang pesat. Berdasarkan data dari BPS Kab. Malang, kunjungan wisatawan domestik diperoleh kurang lebih 3,5 juta dan turis mancanegara terdapat kurang lebih 99 ribu orang. Garis maritim di Kabupaten Malang Selatan telah dimanfaatkan untuk menarik banyak perhatian wisatawan. Kesatuan Pengelolaan Hutan (KPH) Kantor Perhutani Malang menyebutkan bahwa Kabupaten Malang memiliki 101 obyek wisata dan mayoritas adalah wisata pantai, salah satunya adalah Pantai Tiga Warna.

Pantai Tiga Warna terletak di Desa Tambakrejo, Kecamatan Sumbermanjing Wetan, Kabupaten Malang. Pantai Tiga Warna tidak hanya indah, tetapi juga mempunyai kegiatan konservasi dan edukasi. Pantai Tiga Warna termasuk dalam kawasan Clungup Mangrove Conservation (CMC), yang dikelola oleh Kelompok Masyarakat Pengawas (POKMASWAS) Gatra Olah Alam Lestari (GOAL) binaan dari Dinas Kelautan dan Perikanan Provinsi Jawa Timur. POKMASWAS Gatra Olah Alam Lestari secara intensif melakukan kegiatan konservasi melalui Program Pengembangan Desa Pesisir Tangguh (PDPT) dan juga konstribusi berbagai pihak yang juga peduli dengan keselamatan sumber daya alam di pesisir sejak tahun 2013. Sejauh ini kawasan lindung telah mencapai 81 hektar, adapun kegiatan dalam area ini adalah pembibitan dan penanaman mangrove, transplantasi terumbu karang, pendidikan generasi awal melalui aktivitas pendidikan bahari mengenai keamanan 
ekosistem, dan penetasan telur penyu.

Kawasan pantai Tiga Warna termasuk Marine Protected Area (MPA), selain wisatawan yang dibatasi hanya 100 orang per hari, setiap wisatawan yang akan masuk ke pantai Tiga Warna harus diperiksa terlebih dahulu terkait barang bawaan, tidak diperbolehkan membuang sampah sembarangan di kawasan pantai, serta setiap makanan yang dibawa masuk oleh wisatawan harus dibawa kembali sampahnya pada saat mereka keluar dari kawasan Pantai Tiga Warna, dan apabila melanggar maka dikenakan sanksi denda oleh pihak pengelola. Wisatawan tidak hanya dapat melakukan aktivitas berenang, snorkeling, dan diving di Pantai Tiga Warna, tetapi juga dapat menyusuri mangrove dengan perahu, bermain perahu kano, mengunjungi rumah apung, serta melakukan kegiatan konservasi penanaman bibit mangrove, melepas anak penyu dan budidaya terumbu karang buatan. Pantai Tiga Warna menawarkan beberapa paket wisata baik untuk perorangan maupun kelompok dengan harga terjangkau.

Persaingan yang ketat dan tersedianya banyak pilihan dalam bisnis pariwisata di Jawa Timur khususnya di Kabupaten Malang mengharuskan pelaku usaha untuk dapat memperhatikan keunggulan kompetitif dari suatu destinasi wisata seperti dengan menciptakan citra yang positif pada pengunjung dan mempunyai ketersediaan kualitas layanan yang baik, baik dari pekerja maupun pengelola wisata yang ramah dan sopan, begitu juga dengan sarana dan prasarana.

Berdasarkan fenomena yang menjadi acuan, penelitian ini menguji "Pengaruh Citra Destinasi Wisata dan Kualitas Layanan terhadap Kepuasan Pengunjung di Pantai Tiga Warna". Variabel ini penting untuk diteliti karena industri pariwisata di Kabupaten Malang mempunyai persaingan yang ketat dalam beberapa tahun terakhir dan mengharuskan pengelola mempunyai keunggulan kompetitif di masing-masing bidang.

\section{METODE}

Jenis penelitian menggunakan metode penelitian kuantitatif atau metode tradisional, karena sudah cukup lama digunakan sehingga sudah mentradisi sebagai metode untuk penelitian. "Metode ini disebut sebagai metode positivistik karena berlandaskan pada filsafat positivisme. Metode ini sebagai metode ilmiah karena telah memenuhi kaidah-kaidah ilmiah yaitu konkrit/empiris, obyektif, terukur, 
rasional dan sistematis" (Sugiyono, 2012).

Menurut (Metode Penelitian Kuantitatif \& Kualitatif, 2010), populasi adalah "Wilayah generalisasi yang terdiri atas: objek atau subjek yang mempunyai kualitas dan karakteristik tertentu yang ditetapkan oleh peneliti untuk dipelajari dan kemudian di tarik kesimpulannya." Pada penelitian ini terdapat populasi sebesar 16.800 yang didapat dari data historis pengunjung Pantai Tiga Warna, Kabupaten Malang pada periode Januari-Agustus 2020. Besar sampel penelitian karena jumlah populasi tidak diketahui maka peneliti menggunakan pendapat (Hair, Jr, 2015) merekomendasikan jumlah sampel minimal adalah 5 sampai 10 kali dari jumlah item pernyataan yang terdapat dalam kuesioner.

Penarikan sampel pada penelitian ini menggunakan metode purposive sampling yaitu pengambilan sampel dengan memilih beberapa sampel tertentu yang relevan dengan tujuan atau masalah peneliti. Penelitian ini menggunakan skala Likert. Menurut (Rangkuti, 2003) "Dalam skala Likert, kemungkinan jawaban tidak hanya sekadar "setuju" dan "tidak setuju saja, melainkan dibuat dengan lebih banyak kemungkinan jawaban." Penelitian ini menggunakan metode pengumpulan data, yaitu kuesioner, wawancara dan dokumentasi. Penelitian ini menggunakan beberapa metode untuk menganalisis data, yakni uji validitas dan reliablitias, analisa deskriptif, uji asumsi klasik, analisis regresi linear berganda, uji koefisien determinasi dan uji t \& F (hipotesis) yang diolah menggunakan aplikasi SPSS 26.

\section{HASIL DAN PEMBAHASAN}

\section{Uji Validitas}

Pengujian validitas bertujuan untuk mengetahui suatu data dapat dipercaya kebenarannya sesuai dengan kenyataan. Menurut (Yusup et al., 2018), "Instrumen yang valid berarti alat ukur yang digunakan untuk mendapatkan data (mengukur) itu valid, dengan kata lain instrumen tersebut dapat digunakan untuk mengukur apa yang seharusnya diukur." Uji signifikansi dilakukan dengan cara membandingkan nilai $r_{\text {hitung dengan }} r_{\text {tabel }}$ untuk degree of freedom $(\mathrm{df})=n-2$, pada penelitian ini $n$ adalah jumlah sampel yaitu sebesar 100 responden sehingga besarnya df dapat dihitung sebagai 100-2=98. Jika $r_{h i t u n g}>$ dari $r_{\text {tabel }}$ dan bernilai positif, maka dapat disimpulkan indikator valid. Dengan df sebesar 98, dapat diperoleh hasil $r_{\text {tabel }}$ sebesar 0,1966 . 
Tabel 1

Uji Validitas

\begin{tabular}{|c|c|c|c|c|}
\hline $\begin{array}{l}\text { Variabe } \\
1\end{array}$ & Item & $\begin{array}{c}\mathrm{r} \\
\text { Hitung }\end{array}$ & $\begin{array}{l}\mathrm{r} \\
\text { Tabel }\end{array}$ & $\begin{array}{l}\text { Keteranga } \\
\mathrm{n}\end{array}$ \\
\hline \multirow{7}{*}{$\begin{array}{l}\text { Citra } \\
\text { Destinasi } \\
\text { Wisata } \\
\text { (X1) }\end{array}$} & $\begin{array}{l}\mathrm{X} 1 . \\
1\end{array}$ & $\begin{array}{l}0,75 \\
4\end{array}$ & $\begin{array}{l}0,196 \\
6\end{array}$ & Valid \\
\hline & $\begin{array}{l}\mathrm{X} 1 . \\
2\end{array}$ & $\begin{array}{l}0,76 \\
8\end{array}$ & $\begin{array}{l}0,196 \\
6\end{array}$ & Valid \\
\hline & $\begin{array}{l}\mathrm{X} 1 . \\
3\end{array}$ & $\begin{array}{l}0,86 \\
5\end{array}$ & $\begin{array}{l}0,196 \\
6\end{array}$ & Valid \\
\hline & $\begin{array}{l}\mathrm{X} 1 . \\
4\end{array}$ & $\begin{array}{l}0,61 \\
8\end{array}$ & $\begin{array}{l}0,196 \\
6\end{array}$ & Valid \\
\hline & $\begin{array}{l}\mathrm{X} 1 . \\
5\end{array}$ & $\begin{array}{l}0,82 \\
4\end{array}$ & $\begin{array}{l}0,196 \\
6\end{array}$ & Valid \\
\hline & $\begin{array}{l}\mathrm{X} 1 . \\
6\end{array}$ & $\begin{array}{l}0,86 \\
8\end{array}$ & $\begin{array}{l}0,196 \\
6\end{array}$ & Valid \\
\hline & $\begin{array}{l}\text { X1. } \\
7\end{array}$ & $\begin{array}{l}0,64 \\
9\end{array}$ & $\begin{array}{l}0,196 \\
6\end{array}$ & Valid \\
\hline
\end{tabular}

\begin{tabular}{|l|l|l|l|l|}
\hline \multicolumn{1}{|c|}{$\begin{array}{c}\text { Variabe } \\
1\end{array}$} & Item & $\begin{array}{c}\mathrm{r} \\
\text { Hitung }\end{array}$ & $\begin{array}{l}\mathrm{r} \\
\text { Tabel }\end{array}$ & $\begin{array}{l}\text { Keteranga } \\
\mathrm{n}\end{array}$ \\
\hline \multirow{5}{*}{$\begin{array}{l}\text { Kualitas } \\
\text { Layanan }\end{array}$} & $\mathrm{X} 2$. & 0,71 & 0,196 & Valid \\
\cline { 2 - 5 }$(\mathbf{X} 2)$ & $\mathrm{X} 2$. & 0,77 & 0,196 & \multirow{2}{*}{ Valid } \\
\cline { 2 - 5 } & 2 & 5 & 6 & \multirow{2}{*}{ Valid } \\
\cline { 2 - 5 } & $\mathrm{X} 2$. & 0,75 & 0,196 & \multirow{2}{*}{ Valid } \\
\cline { 2 - 5 } & 3 & 6 & 6 & \multirow{2}{*}{ Valid } \\
\cline { 2 - 5 } & $\mathrm{X} 2$. & 0,77 & 6,196 & \\
\hline
\end{tabular}

\begin{tabular}{|l|c|c|l|l|}
\hline \multicolumn{1}{|c|}{ Variabel } & $\begin{array}{l}\text { Ite } \\
\mathrm{m}\end{array}$ & $\begin{array}{c}\mathrm{r} \\
\text { Hitung }\end{array}$ & $\begin{array}{l}\mathrm{r} \\
\text { Tabel }\end{array}$ & $\begin{array}{l}\text { Keteranga } \\
\mathrm{n}\end{array}$ \\
\hline \multirow{3}{*}{$\begin{array}{l}\text { Kepuasan } \\
\text { Pengunjun } \\
\text { g(Y) }\end{array}$} & Y.1 & $\begin{array}{l}0,78 \\
7\end{array}$ & $\begin{array}{l}0,196 \\
6\end{array}$ & Valid \\
\cline { 2 - 5 } & $\mathrm{Y} .2$ & $\begin{array}{l}0,82 \\
5\end{array}$ & $\begin{array}{l}0,196 \\
6\end{array}$ & \multirow{2}{*}{ Valid } \\
\cline { 2 - 5 } & $\mathrm{Y.3}$ & $\begin{array}{l}0,83 \\
8\end{array}$ & $\begin{array}{l}0,196 \\
6\end{array}$ & \multirow{2}{*}{ Valid } \\
\hline
\end{tabular}

Berdasarkan uji validitas yang telah dilakukan keseluruhan item sebagai alat ukur Citra Destinasi Wisata, Kualitas Layanan, dan Kepuasan pengunjung adalah valid dengan nilai $r$ hitung dikeseluruhan item lebih besar dari nilai $r$ tabel.

\section{Uji Reliabilitas}

Berdasarkan uji yang dilakukan, ditemukan bahwa seluruh item dari variabel Citra Destinasi Wisata, Kualitas Layanan dan Kepuasan Pengunjung dinyatakan 
reliabel. Hal ini dapat dilihat pada nilai Cronbach's Alpha yang lebih besar dari 0,6 (Cronbach's Alpha > 0,6), maka dapat disimpulkan bahwa item-item dalam penelitian adalah reliabel.

Tabel 2

Uji Reliabilitas

\begin{tabular}{|l|l|l|l|}
\hline \multicolumn{1}{|c|}{ Variabel } & $\begin{array}{c}\text { Cronba } \\
\text { ch's } \\
\text { Alpha }\end{array}$ & $\begin{array}{c}\text { Nilai } \\
\text { Kritis } \\
(0,6)\end{array}$ & $\begin{array}{c}\text { Keterang } \\
\text { an }\end{array}$ \\
\hline $\begin{array}{l}\text { Citra Destinasi } \\
\text { Wisata (X1) }\end{array}$ & 0,882 & 0,6 & Reliabel \\
\hline $\begin{array}{l}\text { Kualitas Layanan } \\
(\mathrm{X} 2)\end{array}$ & 0,815 & 0,6 & Reliabel \\
\hline $\begin{array}{l}\text { Kepuasan } \\
\text { Pengunjung(Y) }\end{array}$ & 0,749 & 0,6 & Reliabel \\
\hline
\end{tabular}

\section{Uji Normalitas}

Hasil uji normalitas pada penelitian menunjukkan adanya titik-titik menyebar pada sekitar garis diagonal, serta titik-titik menyebar dengan mengikuti arah pada garis diagonal. Dapat disimpulkan bahwa model regresi linier penelitian ini memenuhi asumsi normalitas.

Gambar 1

Uji Normalitas

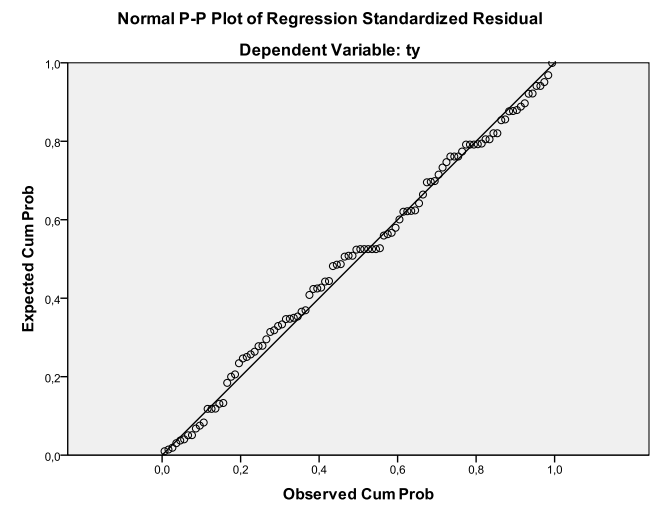

\section{Uji Heteroskedastisitas}

Menurut Ghozali (2018: 134) Uji Heterokedastisitas digunakan untuk: Menguji apakah dalam sebuah model regresi terjadi ketidaksamaan varian dari residual satu pengamatan ke pengamatan yang lain. Jika varian dari residual dari satu pengamatan yang lain maka disebut homokedastisitas dan jika varian berbeda 
disebut heterokedastisitas. Model regresi yang baik adalah homokedastisitas atau tidak heterokedastisitas. Berdasarkan hasil pengolahan dengan menggunakan program SPSS for windows, hasil uji heteroskedastisitas dalam penelitian ini adalah sebagai berikut:

\section{Gambar 2}

\section{Uji Heteroskedastisitas}

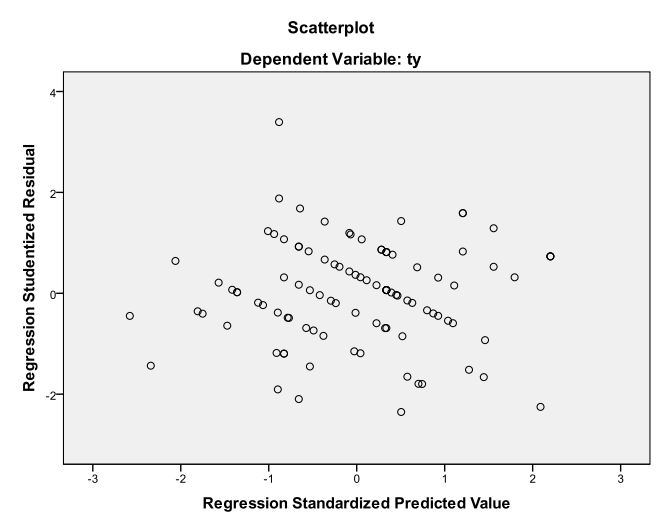

\section{Uji Multikolinearitas}

Berdasarkan hasil pengolahan dengan menggunakan program SPSS for windows, hasil uji multikolinieritas dalam penelitian ini adalah sebagai berikut:

Tabel 3

Uji Multikoliniearitas

\begin{tabular}{|l|c|c|l|}
\hline \multirow{2}{*}{ Variabel } & \multicolumn{2}{|c|}{$\begin{array}{c}\text { Collinearitiy } \\
\text { Statistics }\end{array}$} & \multirow{2}{*}{ Keterangan } \\
\cline { 2 - 3 } & $\begin{array}{c}\text { Toleran } \\
\text { ce }\end{array}$ & VIF & \\
\hline $\begin{array}{l}\text { Citra Destinasi } \\
\text { Wisata (X1) }\end{array}$ & 0,569 & 1,756 & $\begin{array}{l}\text { Tidak terjadi } \\
\text { multikolenieritas }\end{array}$ \\
\hline $\begin{array}{l}\text { Kualitas Layanan } \\
\text { (X2) }\end{array}$ & 0,569 & 1,756 & $\begin{array}{l}\text { Tidak terjadi } \\
\text { multikolenieritas }\end{array}$ \\
\hline
\end{tabular}

Dapat dilihat bahwa nilai VIF variabel Citra Destinasi Wisata (X1) dan Kualitas Layanan (X2) adalah 1.756. Variabel tersebut memiliki VIF $\leq 10$ dan nilai tolerance $\geq 0,10$ maka dapat dikatakan tidak terdapat gejala multikolinieritas.

\section{Koefisien Determinasi $\left(\mathbf{R}^{2}\right)$}

Berdasarkan nilai $\mathrm{R}^{2}$ (Adjusted $R$ Square), dihasilkan 0,417 atau 42\%, sehingga dapat diketahui bahwa besarnya kontribusi pengaruh variabel Citra Destinasi Wisata (X1) dan Kualitas Layanan (X2) terhadap Kepuasan Pengunjung 
(Y) di Pantai Tiga Warna sebesar 42\%, sedangkan sisanya dipengaruhi oleh faktor lain yang tidak diteliti di dalam penelitian ini.

\section{Uji Analisis Regresi Linear Berganda}

Berdasarkan hasil pengolahan dengan menggunakan program SPSS for windows, hasil analisis regresi linier berganda dalam penelitian ini adalah sebagai berikut:

Tabel 3

Uji Analisis Regresi Linear Berganda

\begin{tabular}{|c|c|c|c|c|c|c|}
\hline \multirow{2}{*}{ Model } & \multirow{2}{*}{ var. } & \multicolumn{2}{|c|}{$\begin{array}{l}\text { Unstandarized } \\
\text { Coefficients }\end{array}$} & \multirow{2}{*}{$\begin{array}{c}\begin{array}{c}\text { Standariz } \\
\text { ed } \\
\text { Coefficie } \\
\text { nts }\end{array} \\
\text { Beta }\end{array}$} & \multirow{2}{*}{$\mathbf{t}$} & \multirow{2}{*}{$\begin{array}{c}\mathbf{S i} \\
\mathbf{g}\end{array}$} \\
\hline & & Beta & $\begin{array}{c}\text { Std. } \\
\text { Erro } \\
\text { r }\end{array}$ & & & \\
\hline (Constant) & & $\begin{array}{c}3,37 \\
2\end{array}$ & $\begin{array}{c}2,10 \\
2\end{array}$ & & $\begin{array}{c}1,46 \\
0\end{array}$ & $\begin{array}{c}0,52 \\
7\end{array}$ \\
\hline $\begin{array}{l}\text { Citra Destinasi } \\
\text { Wisata }\end{array}$ & $\mathrm{X} 1$ & $\begin{array}{c}0,34 \\
8 \\
\end{array}$ & $\begin{array}{c}0,10 \\
1 \\
\end{array}$ & 0,243 & $\begin{array}{c}3,43 \\
3\end{array}$ & $\begin{array}{c}0,00 \\
1\end{array}$ \\
\hline $\begin{array}{l}\text { Kualitas } \\
\text { Layanan }\end{array}$ & $\mathrm{X} 2$ & $\begin{array}{c}0,33 \\
7\end{array}$ & $\begin{array}{c}0,06 \\
4\end{array}$ & 0,540 & $\begin{array}{c}5,31 \\
0 \\
\end{array}$ & $\begin{array}{c}0,00 \\
0\end{array}$ \\
\hline $\begin{array}{l}\text { Dependent } \\
\text { Variable }\end{array}$ & \multicolumn{6}{|c|}{ Kepuasan Pengunjung (Y) } \\
\hline Line Equation & \multirow{2}{*}{\multicolumn{6}{|c|}{$\begin{array}{l}Y=a+b_{1} X_{1}+b_{2} X_{2}+e \\
Y=3,372+0,243 X_{1}+0\end{array}$}} \\
\hline Result & & & & & & \\
\hline
\end{tabular}

Berdasarkan penelitian, diketahui persamaan regresi sederhana sebagai berikut:

$$
\begin{aligned}
& Y=a+b_{1} X_{1}+b_{2} X_{2}+e \\
& Y=3,372337+0,348 X_{1}+0,540 X_{2}+e
\end{aligned}
$$

Dari persamaan regresi linier berganda di atas, dapat dijelaskan sebagai a (konstanta $)=3,372$ yang artinya apabila yang artinya apabila variabel bebas yang terdiri dari Citra Destinasi Wisata (X1) dan Kualitas Layanan (X2) diabaikan atau diasumsikan nol, maka variabel Kepuasan Pengunjung (Y) akan bernilai sama dengan nilai konstantanya yaitu sebesar 3,372. Nilai koefisien regresi variabel Citra Destinasi Wisata (X1) sebesar 0,348 bernilai positif. Artinya apabila variabel Citra Destinasi Wisata meningkat sebesar satu satuan dan variabel bebas yang lain 
(Kualitas Layanan) bernilai 0 (nol), maka terbentuknya Kepuasan Pengunjung (Y) akan meningkat sebesar 0,348 .

Nilai koefisien regresi variabel Kualitas Layanan (X2) sebesar 0,540 bernilai positif. Artinya apabila variabel Kualitas Layanan meningkat sebesar satu satuan dan variabel bebas yang lain (Citra Destinasi Wisata) bernilai 0 (nol), maka terbentuknya Kepuasan Pengunjung (Y) akan meningkat sebesar 0,540.

\section{Uji t}

Berdasarkan tabel diatas, maka dapat dikatakan bahwa nilai thitung untuk variabel Citra Destinasi Wisata (X1) adalah sebesar 3,433 dan memiliki nilai signifikansi 0,001 maka dapat diambil kesimpulan $t_{\text {hitung }} 3,433>t_{\text {tabel }}$ 1,985 dan dengan nilai signifikansi $0,001<0,050(0,05)$. Hal ini menunjukkan $\mathrm{H} 0$ ditolak dan Ha diterima. Dengan demikian dapat diambil kesimpulan bahwa Citra Destinasi Wisata berpengaruh positif dan signifikan terhadap Kepuasan Pengunjung (Y) mengunjungi Pantai Tiga Warna. Nilai thitung untuk variabel Kualitas Layanan (X2) adalah sebesar 5,310 dan memiliki nilai signifikansi 0,000 maka dapat diambil kesimpulan thitung 5,310 $>\mathrm{t}_{\text {tabel }} 1,985$ dan dengan nilai signifikansi $0,000<0,050$ $(0,05)$. Hal ini menunjukkan H0 ditolak dan Ha diterima. Dengan demikian dapat diambil kesimpulan bahwa Kualitas Layanan (X2) berpengaruh positif dan signifikan terhadap Kepuasan Pengunjung (Y) mengunjungi Pantai Tiga Warna.

\section{Uji F}

Penelitian menunjukkan nilai $F_{\text {hitung }} 36,427$, dengan signifikan sebesar 0,000. Maka nilai $F_{\text {hitung }}>F_{\text {tabel yaitu 36,427 }}>3,09$ dengan nilai signifikansi 0,000 $<0,05$. Dapat disimpulkan bahwa Ho ditolak dan Ha diterima. Dengan demikian dapat diambil kesimpulan bahwa variabel Citra Destinasi Wisata (X1) dan Kualitas Layanan (X2) secara bersama-sama berpengaruh positif dan signifikan terhadap Kepuasan Pengunjung (Y) mengunjungi Pantai Tiga Warna.

\section{Pembahsan}

Penelitian melibatkan 100 responden sebagai sampel. Berdasarkan data yang telah diperoleh melalui uji $\mathrm{t}$, dapat diketahui jika pengujian hipotesis secara parsial menggunakan uji t menyatakan bahwa variabel Citra Destinasi Wisata (X1) secara parsial berpengaruh positif dan signifikan terhadap Kepuasan Pengunjung 
(Y). Hal ini dapat dilihat dari nilai thitung sebesar 3,433, lebih besar dari tabel dengan nilai 1,985 dan dengan nilai signifikansi lebih kecil dari 0,050 yaitu sebesar 0,001 . Dengan demikian dapat diambil kesimpulan bahwa Citra Destinasi Wisata (X1) berpengaruh positif dan signifikan terhadap Kepuasan Pengunjung (Y) di Pantai Tiga Warna. Penelitian ini mendukung dari hasil penelitian sebelumnya yang dilakukan oleh Gustiana, et. al. (2020) yang menyatakan bahwa terdapat pengaruh antara citra destinasi terhadap kepuasan wisatawan pada objek wisata Gunung Dempo Kota Pagar Alam Sumatera Selatan.

Berdasarkan data yang telah diperoleh melalui hasil uji t, variabel Kualitas Layanan (X2) secara parsial juga berpengaruh positif dan signifikan terhadap Kepuasan Pengunjung (Y). Hal ini dapat dilihat dari nilai thitung sebesar, 5,310 lebih besar dari tabel dengan nilai 1,985 dan nilai signifikansi lebih kecil dari 0,05 yaitu sebesar 0,000 Dengan demikian dapat diambil kesimpulan bahwa Kualitas Layanan (X2) berpengaruh positif dan signifikan terhadap Kepuasan Pengunjung (Y) di Pantai Tiga Warna. Penelitian ini mendukung dari hasil penelitian sebelumnya yang dilakukan oleh Stella, et.al. (2015) yang menyatakan Kualitas Pelayanan Objek Wisata, secara parsial berpengaruh terhadap Kepuasan Wisatawan, serta penelitian dari Wijaya, Fahmy dan Sujana (2020) yang menyatakan bahwa variabel Kualitas Layanan berpengaruh signifikan terhadap Kepuasan Pelanggan The Jungle Waterpark.

Hasil penelitian ini menyatakan bahwa Citra Destinasi Wisata (X1) dan Kualitas Layanan (X2) secara simultan memiliki pengaruh yang positif dan signifikan terhadap terhadap Kepuasan Pengunjung (Y) di Pantai Tiga Warna. Hal tersebut dapat dilihat berdasarkan tabel hasil uji $\mathrm{F}$, diperoleh $\mathrm{F}_{\text {hitung }}$ sebesar 36,427 dengan tingkat signifikansi 0,000 dan telah diperoleh nilai $F_{\text {tabel }}$ sebesar 3,09. Dengan demikian $F_{\text {hitung }}>F_{\text {tabel }}$ yaitu 36,427 > 3,09 dengan nilai signifikansi 0,000 $<0,05$. Hal ini menunjukkan $\mathrm{H}_{0}$ ditolak dan $\mathrm{H}_{\mathrm{a}}$ diterima. Dengan demikian dapat diambil kesimpulan bahwa variabel Citra Destinasi Wisata (X1) dan Kualitas Layanan (X2) secara bersama-sama berpengaruh positif dan signifikan terhadap Kepuasan Pengunjung (Y) di Pantai Tiga Warna. Penelitian ini mendukung dari hasil penelitian sebelumnya yang dilakukan oleh Safitasari dan Ida Maftukhah (2017) yang menyatakan bahwa terdapat pengaruh kualitas layanan, promosi, dan 
citra destiansi terhadap kepuasan pengunjung baik secara langsung maupun tidak langsung, semakin tinggi tingkat kualitas layanan, promosi, dan citra destinasi maka dapat mempengaruhi keputusan berkunjung yang akan berdampak pada kepuasan pengunjung.

Hasil analisis regresi linear berganda, diperoleh persamaan regresi yaitu $\mathrm{Y}=3,372+0,243 \mathrm{X}_{1}+0,540 \mathrm{X}_{2}+$ e. Dari persamaan regresi linier berganda, dapat dijelaskan sebagai a (konstanta) $=3,372$ yang artinya apabila variabel bebas yang terdiri dari Citra Destinasi Wisata (X1) dan Kualitas Layanan (X2) diabaikan atau diasumsikan nol, maka variabel Kepuasan Pengunjung (Y) akan bernilai sama dengan nilai konstantanya yaitu sebesar 3,372. Nilai koefisien regresi variabel Citra Destinasi Wisata (X1) sebesar 0,243 bernilai positif. Artinya apabila variabel Citra Destinasi Wisata meningkat sebesar satu satuan dan variabel bebas yang lain (Kualitas Layanan) bernilai 0 (nol), maka terbentuknya Kepuasan Pengunjung (Y)meningkat sebesar 0,243. Nilai koefisien regresi variabel Kualitas Layanan (X2) sebesar 0,540 bernilai positif. Artinya apabila variabel Kualitas Layanan meningkat sebesar satu satuan dan variabel bebas yang lain (Citra Destinasi Wisata) bernilai 0 (nol), maka terbentuknya Kepuasan Pengunjung (Y) akan meningkat sebesar 0,540. Dengan demikian dapat diketahui bahwa variabel Kualitas Layanan (X2) lebih berpengaruh daripada variabel Citra Destinasi Wisata (X1) terhadap Kepuasan Pengunjung (Y) Pantai Tiga Warna. Besarnya kontribusi Citra Destinasi Wisata (X1) dan Kualitas Layanan (X2) terhadap Kepuasan Pengunjung (Y) dapat diketahui melalui koefisien determinasi ( $\mathrm{R}^{2}$ Adjusted $R$ Square) yaitu 42\%.

Hasil penelitian ini menunjukkan bahwa Citra Destinasi Wisata dan Kualitas Layanan baik secara parsial ataupun simultan memiliki pengaruh yang positif dan signifikan terhadap Kepuasan Pengunjung di Pantai Tiga Warna Hal tersebut sesuai dengan yang ada, karena Pantai Tiga Warna memberi kenyamanan saat berada di destinasi wisata, pengunjung menilai bahwa Pantai Tiga Warna adalah salah satu tujuan wisata yang diinginkan, pihak pengelola memelihara hubungan yang baik dengan pengunjung, pihak pengelola mempunyai komunikasi yang baik dengan pengunjung, serta pengunjung percaya bahwa pemilihan berkunjung ke Pantai Tiga Warna adalah hal yang tepat. 


\section{SIMPULAN DAN REKOMENDASI}

Dari hasil penelitian yang diuji dengan 100 responden menunjukkan bahwa variabel Citra Destinasi Wisata dan Kualitas Layanan memiliki pengaruh terhadap Kepuasan Pengunjung. Berdasarkan hasil pengujian secara parsial (Uji t) dapat diketahui bahwa variabel Citra Destinasi Wisata secara parsial berpengaruh positif dan signifikan terhadap Kepuasan Pengunjung di Pantai Tiga Warna. Sedangkan variabel Kualitas Layanan secara parsial juga berpengaruh positif dan signifikan terhadap Kepuasan Pengunjung di Pantai Tiga Warna. Berdasarkan hasil pengujian secara simultan (Uji F) dapat diketahui bahwa variabel Citra Destinasi Wisata dan Kualitas Layanan secara bersama-sama berpengaruh positif dan signifikan terhadap Kepuasan Pengunjung di Pantai Tiga Warna. Hasil penelitian ini menunjukkan bahwa Citra Destinasi Wisata dan Kualitas Layanan baik secara parsial ataupun simultan memiliki pengaruh yang positif dan signifikan terhadap Kepuasan Pengunjung di Pantai Tiga Warna. Penelitian ini dapat dikembangkan dengan memberikan atau menambahkan variable system informasi pemasaran atau kualitas informasi yang ada seperti yang dilakukan oleh (Pratama et al., 2021) (Alvianna, Earlike, et al., 2020) Serta dengan melihat atraksi amenitas dan aksesibiltas yang ada (Alvianna, Patalo, et al., 2020)(Wibowo et al., 2021) selain itu factor media social dalam pemasaran destinasi juga perlu di maksimalkan mengingat saat ini usia millennial yang mendominasi penguasaan media social (Amelia, Rizka; Hidayatullah, 2020) dengan secara konsistem memperhatikan kualitas dari system informasi dari media social atau website yang ada (Hidayatullah, 2020)(Shodiq et al., 2018)(Syarif, 2020), fasilitas juga perlu diperhatikan (Sandrio et al., 2020)(Alvianna \& , Alviandra, 2020) , persperktif pariwisata daerah juga perlu di pahami sehingga intervensi kebijakan tentang pariwisata dapat dengan baik terwijud (Anibal MJ N'dami et al., 2021). Selain hal tersebut pengelolaan destinasi juga hendaknya memperhatikan kelompok sadar wisata yang ada di daerah sertempat (Hidayatullah et al., 2017) (Hidayatullah et al., 2018), serta bagaimana marketing information destinastion yang ada (Wibowo et al., 2021)(Eman et al., 2021) dapat sebagai bahan kajian penelitian berikutnya. 


\section{DAFTAR PUSTAKA (A.P.A. Style)}

Alvianna, S., \& , Alviandra, R. (2020). Pengaruh Destinasi Wisata dan Kepuasan Wisatawan Terhadap Minat Berkunjung Kembali di Kampung Wisata Topeng Malang Pengaruh Destinasi Wisata dan Kepuasan Wisatawan Terhadap Minat Berkunjung Kembali di Kampung Wisata Topeng Malang. December.

Alvianna, S., Earlike, F., Sani, A., Lasarudin, A., \& Hidayatullah, S. (2020). The Impact of Visitor Satisfaction Mediation from the Relationship between Marketing Information Systems, Tourist Destinations and Service Quality towards Returning Interest in Malang Topeng Village Tourism Destinations. 4413(12), 332-338. https://doi.org/10.36349/easjmb.2020.v03i12.003

Alvianna, S., Patalo, R. G., Hidayatullah, S., \& Rachmawati, I. K. (2020). Pengaruh Attraction, Accessibillity, Amenity, Ancillary Terhadap Kepuasan Generasi Millenial Berkunjung ke Tempat Wisata. 4, 53-59. https://doi.org/10.34013/jk.v4i2.41

Amelia, Rizka; Hidayatullah, S. (2020). The Effect of Instagram Engagement to Purchase Intention and Consumers 'Luxury Value Perception as the mediator in the Skylounge Restaurant. 5(4), 958-966.

Anibal MJ N'dami, C. ;, Syarif, H. ;, Stella, A. ;, Muhammad Danang, S. ;, \& Rulli, K. (2021). PRESPECTIVE OF TOURISM DEVELOPMENT IN BIJAGOS ISLAND ( GUINEA-BISSAU ) AS WELL AS COMMUNITY ECONOMIC GROWTH. 9(1), 3766-3773.

Asmoro, D. R., \& Maftukhah, I. (2017). Pengaruh Kualitas Layanan, Citra Merk Dan Inovasi Layanan Terhadap Kepuasan Pasien Rawat Inap Pada Rs Keluarga Sehat Di Kab Pati. Management Analysis Journal.

Baloglu, S., \& McCleary, K. W. (1999). A model of destination image formation. Annals of Tourism Research. https://doi.org/10.1016/S0160-7383(99)000304

Buhalis, D. (2000). Marketing the competitive destination of the future. Tourism Management. https://doi.org/10.1016/S0261-5177(99)00095-3

Carman, J. M. (1990). Consumer perceptions of service quality: an assessment of the SERVQUAL dimensions. Journal of Retailing $V O$ - 66.

Çoban, S. (2012). The effects of the image of destination on tourist satisfaction and loyalty: The case of Cappadocia. European Journal of Social Sciences.

Donni, P. J. (2017). Perilaku Konsumen Dalam Persaingan Kontemporer. In alfabeta.

Eman, E. M., Alvianna, S., Hidayatullah, S., \& Lazaruddin, A. (2021). The Influence of Social Media on Tourists Visiting Lake Weekuri Southwest Sumba. 6(1), 538-542.

Hair, Jr, J. F. (2015). Essentials of Business Research Methods. In Essentials of Business Research Methods. https://doi.org/10.4324/9781315704562

Hidayatullah, S. (2020). Website Quality: The Effect with Perceived Flow and Purchase Intention in Travel Customers in Malang City. 5(11).

Hidayatullah, S., Malang, U. M., Khouroh, U., Malang, U. M., Windhyastiti, I., \& Malang, U. M. (2018). Development of Tourist Village Model Through "Pokdarwis" Empowerment and Information Technology Utilization. European Journal of Business and Management, January. https://doi.org/10.7176/ejbm-10-23-12

Hidayatullah, S., Rachmawati, I. K., \& Khouroh, U. (2017). The Effectivity of 
“Pokdarwis ” Role on Successfully Marketing of Tourism Village Towards

“Mega Tourism : Batu City For The World .” August, 978-979.

Hidayatullah, S., Windhyastiti, I., Patalo, R. G., \& Rachmawati, I. K. (2020). Citra Destinasi : Pengaruhnya terhadap Kepuasan dan Loyalitas Wisatawan yang Berkunjung ke Gunung Bromo. 96-108.

Hosany, S., Ekinci, Y., \& Uysal, M. (2007). Destination image and destination personality. International Journal of Culture, Tourism and Hospitality Research. https://doi.org/10.1108/17506180710729619

Jenkins, O. H. (1999). Understanding and measuring tourist destination images. International Journal of Tourism Research. https://doi.org/10.1002/(sici)1522-1970(199901/02)1:1<1::aidjtr143>3.3.co;2-c

Kotler dan Keller. (2017). Manajemen Pemasaran, Edisi 12, Jilid 1, PT.Indeks,. Jakarta. In $e-J u r n a l$ Riset Manajemen.

Lopes, S. D. F. (2011). Destination image: Origins, Developments and Implications. PASOS. Revista de Turismo y Patrimonio Cultural. https://doi.org/10.25145/j.pasos.2011.09.027

Oroh, S., Mananeke, L., \& Sangkaeng, S. (2015). PENGARUH CITRA, PROMOSI DAN KUALITAS PELAYANAN OBJEK WISATA TERHADAP KEPUASAN WISATAWAN DI OBJEK WISATA TAMAN LAUT BUNAKEN SULAWESI UTARA. Jurnal Riset Ekonomi, Manajemen, Bisnis Dan Akuntansi. https://doi.org/10.35794/emba.v3i3.10113

Philip Kotler dan Gery Amstrong. (2012). pengaruh lokasi, kualitas pelayanan terhadap keputusaan pembelian. HIFADH.

Pratama, B. P., Hidayatullah, S., \& Alvianna, S. (2021). Mediation Effect of Customer Satisfaction from the Relationship between System Quality , Information Quality, and Service Quality towards Interests of Tourist Visiting in East Java Park 3. 6(1), 95-100.

Rangkuti, F. (2003). Measuring customer satisfaction: teknik mengukur dan strategi meningkatkan kepuasan pelanggan plus analisis kasus $\{P L N\}-\{J P\}$. In Gramedia Pustaka Utama.

Sandrio, L., Hidayatullah, S., Supriadi, B., \& Patalo, R. G. (2020). Effect Of Tourism Satisfaction As A Mediator Variable Of Images Of Destination And Facilities To Loyalties On Millenial Generation To Visit Bromo Tengger Semeru. 9(05), 183-187.

Shodiq, A. F., Hidayatullah, S., \& Ardianto, Y. T. (2018). INFLUENCE OF DESIGN, INFORMATION QUALITY AND CUSTOMER SERVICES WEBSITE ON CUSTOMER SATISFACTION. 9(12), 746-750. https://www.researchgate.net/publication/338403234_INFLUENCE_OF_D ESIGN_INFORMATION_QUALITY_AND_CUSTOMER_SERVICES_W EBSITE_ON_CUSTOMER_SATISFACTION

Sugiyono. (2012). Metode Penelitian Kuantitatif, Kualitatif dan R \& D.Bandung:Alfabeta. Metode Penelitian Kuantitatif, Kualitatif Dan $R$ \& D.Bandung:Alfabeta. https://doi.org/10.1017/CBO9781107415324.004

Metode Penelitian Kuantitatif \& kualitatif, Journal of Experimental Psychology: General (2010).

Syarif, H. at all. (2020). ALAM WEBSITE, sejarah, jenis, manfaat, kejahatan dan solusi pada alam website (1st ed.). Uwais Inspirasi Indonesia. 
Tjiptono, \& Fandy. (2015). Strategi Pemasaran. In Yogyakarta: Andi.

Wibowo, R., Alvianna, S., Hidayatullah, S., Astuti, W., \& Setioko, D. (2021). Analysis of the Influence of Tourist Destinations and Service Quality on Tourist Satisfaction Visiting the Jawa Timur Park in the New Normal Era. 6(1), 295-300.

Yusup, F., Studi, P., Biologi, T., Islam, U., \& Antasari, N. (2018). Uji Validitas Dan Reliabilitas. Jurnal Tarbiyah: Jurnal Ilmiah Kependidikan. 